\title{
Spirituality and Health: A Middle Eastern Perspective
}

\author{
Elizabeth Weathers
}

School of Nursing and Midwifery, RCSI Bahrain, P.O. Box 15503, Adliya 15503, Kingdom of Bahrain; eweathers@rcsi.com

Received: 6 December 2017; Accepted: 16 January 2018; Published: 23 January 2018

\begin{abstract}
Previous spirituality studies have mostly been conducted in a Western context (Moberg 2002; Koenig et al. 2012). However, an increasing number of studies are originating from Middle Eastern countries (Koenig et al. 2012). There is a need to review the current status of Middle Eastern research to identify priorities for future research. A search was conducted in two electronic databases: CINAHL and Medline. A final sample of 28 articles was included in the review. Eighteen articles reported on quantitative studies and ten reported on qualitative studies. The majority of previous research has been conducted in Iran $(n=16)$ and Jordan $(n=6)$. A total of 3096 participants were included in the studies ranging from 2004 to 2017. Two studies were randomised controlled trials. Most of the qualitative studies aimed to gain a deeper understanding of the concept of spirituality from a Muslim-Arabic perspective. Qualitative findings have conceptualised spirituality as meaning in life, connection, peace and transcendence. In conclusion, there are both differences and similarities between Middle Eastern and Western research on spiritualty and health. Further exploration is warranted to include comparative studies between patient and nurse populations in Western societies and in the Middle East.
\end{abstract}

Keywords: spirituality; spiritual wellbeing; literature review; Middle East; Arabic; Islam; health

\section{Introduction}

Spirituality is a complex, but important concept. Its importance is reflected in the increased research on the topic (Lucchetti and Lucchetti 2014), as well as the inclusion of spirituality and spiritual care in healthcare policy across the globe. For example, the National Health Service (NHS) Scotland published an educational document for healthcare staff (NHS 2009). Similarly, the government in Manitoba in Canada, published a list of core competencies for spiritual health care practitioners (Manitoba's Spiritual Health Care Partners 2017). Furthermore, many professional regulatory bodies now include the provision of spiritual care in their recommendations and guidance to healthcare professionals. For example, the International Council of Nurses refers to spiritual care in their Code of Ethics document (ICN 2012). Similarly, in the UK, the Nursing and Midwifery Council (NMC) have referred to spiritual care in their standards for both pre-registration nurses and registered nurses (NMC 2010, 2014). In Ireland, the Nursing and Midwifery Board of Ireland refer to spiritual aspects of care in their scope of practice framework (NMBI 2015), requirements for nurse registration education programmes (NMBI 2005) and guidance for working with older people (NMBI 2009).

The increasing interest in spirituality has stemmed from changes in culture, religion and society. This has been particularly evident in Western Society in terms of a shift away from institutionalized religion and movement towards more individualised type religion e.g., a personal search for meaning, a sense of self and enhanced connection with others (Puchalski et al. 2014). This has led to an increased focus on spirituality and spiritual concepts across many fields including healthcare (Cockell and McSherry 2012; Monod et al. 2011; Pike 2011; Williams and Sternthal 2007) and business or workplace literature (Crossman 2010, 2011; Karakas 2010; Pawar 2009; Phipps 2012). Spirituality has almost become regarded as a new concept, with a lack of recognition amongst some authors of 
the historical and traditional association between spirituality, religion and health. The discourse and language used to describe spirituality and spiritual concepts has changed. Consequently, there has been a search for words to describe the concept of spirituality that are not couched in religious meaning. From a healthcare perspective, this has been a challenge, and is reflected in the many published papers that strive to clarify the concept of spirituality and differentiate it from related concepts such as religiosity, spiritual wellbeing, spiritual health etc. (Weathers et al. 2016).

The majority of previous research on spirituality has been conducted with Western populations (Moberg 2002; Koenig et al. 2012). Yet, an increasing number of studies are emerging from Middle Eastern countries conducted with predominantly Muslim populations and investigating relationships between spirituality and variables such as wellbeing, hope, meaning, self-esteem and depression (Jafari et al. 2014b; Koenig et al. 2012). In terms of understandings of spirituality in a Middle Eastern and Muslim context, Rassool (2000) published seminal work on the topic of healing, nursing and the spiritual dimension. According to Rassool, there is no distinction between spirituality and religion in a Muslim context. Muslim individuals live in a manner in which their religious beliefs pervade all of their actions and across all facets of human life, including their work life (Rassool 2000). With regard to spiritual care, Rassool (2000) concluded that nursing care models practised within a Judeo-Christian tradition lack a religious focus and thus are not appropriate to meet the needs of Muslim patients. The need to develop nursing models of care that are appropriate to both Muslims and non-Muslims was emphasised by Rassool (2000). Similarly, Jafari et al. (2014a) reported that in an Islamic context, religion and spirituality are often not differentiated and practical models of care are needed to better integrate spirituality into healthcare. However, Jafari et al. (2014a) further concluded that while spirituality and religion may not be differentiated in an Islamic context, spiritual care consists of more than just religious care; it provides a framework for healthcare professionals to connect with patients and deliver person-centered, holistic care. Seeking further clarity of spiritual concepts in an Islamic context, Heydari et al. (2016) conducted a concept analysis using a modified hybrid model to better understand the concept of spiritual health in the context of the practice of Islam among Iranian patients. The analysis consisted of five phases: theoretical phase, initial fieldwork phase, initial analytical phase, final-fieldwork phase and final analytical phase. Findings of this study identified the following six critical attributes of spiritual health: love of the Creator, duty-based life, religious rationality, psychological balance, attention to afterlife, and holy morals. Heydari et al. (2016) concluded that spiritual health from a Muslim perspective does not develop with consideration of any god, but rather with consideration only of Allah as the Ultimate. Similar to above earlier findings, Heydari et al. (2016) also concluded that spiritual health from a Muslim perspective encompasses all aspects of a person's life. Meanwhile, Ahmad and Khan (2016) expanded on the above prior research by proposing a model of spirituality that is applicable to Muslims of any age, but especially applicable to older Muslims. The model was informed by the teachings of Islam and consisted of seven basic functions of spirituality: translation of life's experiences and events into a deeper understanding; transaction i.e., relationships with every living human and thing; transformation of self through cleansing and religious purification; transition into an afterlife; transference i.e., moving from feelings of frustration to seeking relief from life's burdens and anxieties by trusting in Allah; transcendence i.e., coming closer than ever before to Allah through an extraordinary experience; and transposition i.e., a change in priorities when a Muslim pursues less and less of the material world and more connection with Allah.

In summary, the majority of people in the Middle East follow Islamic religion and traditions and thus, it is evident that conceptualisations of spirituality amongst populations in the Middle East differ from Western populations. From an Islamic perspective, spirituality and religion are often intertwined with one another and pervade all aspects of a person's life (Ahmad and Khan 2016; Heydari et al. 2016; Jafari et al. 2014a; Rassool 2000). Yet, it is acknowledged that spiritual care does not equate only to religious care and there is a need to develop models for the provision of spiritual care that are appropriate in an Islamic healthcare context (Jafari et al. 2014a; Rassool 2000). Ahmad and Khan (2016) developed a model of spirituality based on the teachings of Islam to help contextualize spirituality 
from a Muslim's perspective, and especially an ageing Muslim. In light of this increased interest in spirituality amongst scholars in the Middle East, there is a need to review the current status of research in this region and identify priorities for future research. A review of the Middle Eastern literature would also highlight any similarities or differences from research conducted with Western populations.

\section{Materials and Methods}

The aim of this research was to identify and summarize the research conducted to date on the topic of spirituality and health within a Middle Eastern context. A systematic approach to the review was adopted. A search was conducted in two electronic databases: CINAHL and Medline. The following search terms were used: spiritual, spirituality, Middle East, Arabic, Muslim, Islam and health. Searches were conducted using Boolean operators AND and OR to narrow and broaden the search. No search limits were applied. Articles were included if they focused on spirituality in the context of healthcare, were published in a peer-reviewed journal in English, and were conducted with a Middle Eastern sample. Articles not related to health or that didn't include a sample from the Middle East were excluded, as were books and theses. Thirty-nine citations were sourced in CINAHL and ninety-one in Medline. A final sample of 31 articles was included in the review, after applying inclusion and exclusion criteria.

\section{Results}

Eighteen quantitative studies and ten qualitative studies that have been conducted in the Middle Eastern region on the topic of spirituality were sourced (see Table 1 for an overview of included studies). A total of 3096 participants were included in the studies ranging from 2004 to 2017. Most studies were conducted in Iran $(n=16)$. The remaining studies were conducted in Jordan $(n=6)$, Pakistan $(n=2)$, Saudi Arabia $(n=2)$, Turkey $(n=1)$, and Israel $(n=1)$. Nine studies were conducted with cancer patients, 4 of which were women with breast cancer and 1 study was with breast cancer survivors. Six studies included nurses and one of these studies recruited a mixed patient, nurse and doctor sample. The remaining studies included patients on haemodialysis $(n=3)$, patients with Type 2 Diabetes Mellitus $(n=1)$, older adults with hypertension $(n=1)$, men with Coronary Artery Disease $(n=1)$, pregnant mothers $(n=1)$, children with asthma $(n=1)$, men with post-traumatic stress disorder $(n=1)$, men in addiction treatment $(n=1)$, parents of patients with thalassemia $(n=1)$, patients with anxiety disorder $(\mathrm{n}=1)$ and high school female students $(\mathrm{n}=1)$. 
Table 1. Overview of Included Studies.

\begin{tabular}{|c|c|c|c|}
\hline Author (Year), Country & Aim & Design & Sample and Data Collection \\
\hline \multicolumn{4}{|c|}{ Quantitative Studies } \\
\hline $\begin{array}{l}\text { Bakir et al. (2017) } \\
\text { Turkey }\end{array}$ & $\begin{array}{l}\text { To determine the experiences and perceptions of } \\
\text { intensive care nurses (ICNs) about spirituality and } \\
\text { spiritual care. }\end{array}$ & Quantitative descriptive & $\begin{array}{l}\text { The Spirituality and Spiritual Care rating scale (McSherry et al. 2002) } \\
\text { was used to survey ICNs }(n=145) \text {. }\end{array}$ \\
\hline $\begin{array}{l}\text { Al-Natour et al. (2017) } \\
\text { Jordan }\end{array}$ & $\begin{array}{l}\text { To investigate the relationship between } \\
\text { spirituality and quality of life. }\end{array}$ & Descriptive correlational & $\begin{array}{l}\text { The Arabic version of the Functional Assessment of Chronic Illness } \\
\text { Therapy-Spiritual Well-being (FACIT-SWB)(Peterman et al. 2002) } \\
\text { was used to collect data from Jordanian women with breast cancer } \\
(\mathrm{n}=150) \text {. }\end{array}$ \\
\hline $\begin{array}{l}\text { Cruz et al. (2017) } \\
\text { Saudi Arabia }\end{array}$ & $\begin{array}{l}\text { To explore the influence of religiosity and spiritual } \\
\text { coping on health-related quality of life. }\end{array}$ & $\begin{array}{l}\text { Descriptive correlational (conducted regression } \\
\text { analysis) }\end{array}$ & $\begin{array}{l}\text { Religiosity was measured using the Muslim Religious Index } \\
\text { (Al Zaben et al. 2015); spiritual coping usage was measured using } \\
\text { the Arabic version of the Spiritual Coping Strategies scale } \\
\text { (Cruz et al. 2016); and health-related quality of life was measured } \\
\text { using the Arabic version of Ferrans and Powers Quality of Life Index } \\
\text { Dialysis Version-III (Halabi 2006). A sample of patients receiving } \\
\text { haemodialysis ( } \mathrm{n}=168 \text { ) was recruited. }\end{array}$ \\
\hline $\begin{array}{l}\text { Musa (2017) } \\
\text { Jordan }\end{array}$ & $\begin{array}{l}\text { To explore the frequency of providing aspects of } \\
\text { spiritual care intervention and its association with } \\
\text { nurses' own spiritual wellbeing. }\end{array}$ & Descriptive correlational & A sample of Jordanian Arab Muslim nurses $(\mathrm{n}=355)$ was recruited. \\
\hline $\begin{array}{l}\text { Moeini et al. (2016) } \\
\text { Iran }\end{array}$ & $\begin{array}{l}\text { To examine the effect of Islam-based religious } \\
\text { interventions on spiritual wellbeing. }\end{array}$ & $\begin{array}{l}\text { Randomised controlled trial of an Islam-based } \\
\text { religious programme consisting of } 8 \text { sessions in } \\
2 \text { health centres. }\end{array}$ & $\begin{array}{l}\text { Older adults with hypertension }(\mathrm{n}=52) \text { who were referred to the } \\
\text { health centres of Isfahan in 2014. Intervention group }(\mathrm{n}=26) \text { and } \\
\text { control group }(\mathrm{n}=26) \text {. The Spiritual Well-Being scale } \\
\text { (Paloutzian and Ellison 1982) was completed pre-test, post-test, and } \\
\text { after } 1 \text { month of follow up. }\end{array}$ \\
\hline $\begin{array}{l}\text { Hosseini et al. (2016) } \\
\text { Iran }\end{array}$ & $\begin{array}{l}\text { To test the effect of a spiritual intervention on } \\
\text { dopamine gene receptor (DRD1-5) expressions. }\end{array}$ & $\begin{array}{l}\text { Randomised controlled trial of an intervention } \\
\text { focused on the concepts of prayer, patience, } \\
\text { reliance, self-sacrifice, forgiveness, altruism, } \\
\text { kindness, remission, repentance, thankfulness, } \\
\text { meditation, mantra and death. It complemented } \\
\text { conventional treatments that patients were } \\
\text { receiving for cancer. } 10 \text { weekly sessions were } \\
\text { delivered and each session was } 90 \text { min. }\end{array}$ & $\begin{array}{l}\text { Breast cancer patients }(n=57) \text {. Intervention group }(n=28) \text { and } \\
\text { control group }(n=29) \text {. Blood samples collected before and after } \\
\text { implementation of the spiritual intervention to analyse changes in } \\
\text { dopamine gene receptor expressions. Blood samples were also } \\
\text { collected from healthy individuals as a control. }\end{array}$ \\
\hline $\begin{array}{l}\text { Cruz et al. (2016) } \\
\text { Saudi Arabia }\end{array}$ & $\begin{array}{l}\text { To assess the validity and reliability of the } \\
\text { Spiritual Coping Strategies Scale Arabic version } \\
\text { (SCS-A). }\end{array}$ & Descriptive correlational & $\begin{array}{l}\text { A sample of patients undergoing haemodialysis }(\mathrm{n}=60) \text { was } \\
\text { recruited. Internal consistency reliability, stability reliability, factor } \\
\text { analysis and construct validity tests were performed. }\end{array}$ \\
\hline $\begin{array}{l}\text { Anum and Dasti (2016) } \\
\text { Pakistan }\end{array}$ & $\begin{array}{l}\text { To determine the relationship of caregiver burden, } \\
\text { spirituality and psychological well-being. }\end{array}$ & Descriptive correlational & $\begin{array}{l}\text { A sample of parents of Pakistani thalassemic patients ( } \mathrm{n}=80 \text { ) was } \\
\text { recruited. Spirituality was measured using the Multidimensional } \\
\text { Measure of Islamic Spirituality (Dasti and Sitwat 2014); psychological } \\
\text { well-being was measured using the Ryff Scale of Psychological } \\
\text { Well-being (Ryff 1989); and caregiving burden was measured using } \\
\text { the Montgomery-Borgatta burden measure (Montgomery et al. 2000). }\end{array}$ \\
\hline
\end{tabular}


Table 1. Cont.

\begin{tabular}{|c|c|c|c|}
\hline Author (Year), Country & Aim & Design & Sample and Data Collection \\
\hline $\begin{array}{l}\text { Rezazadeh et al. (2015) } \\
\text { Iran }\end{array}$ & $\begin{array}{l}\text { To investigate determinants of responsibility for } \\
\text { health, spiritual health and interpersonal relations } \\
\text { and predictive factors based on the theory of } \\
\text { planned behaviour. }\end{array}$ & Descriptive correlational & $\begin{array}{l}\text { A sample of high school female students in Tabriz }(\mathrm{n}=340) \text {. } \\
\text { Spiritual health standards, components of the TPB, and health } \\
\text { promotion and lifestyle were measured using an author-developed } \\
\text { questionnaire based on the following instruments: Health Promotion } \\
\text { and Lifestyle II, the Spiritual Wellbeing scale } \\
\text { (Paloutzian and Ellison 1982), and components of the theory of } \\
\text { planned behaviour. }\end{array}$ \\
\hline $\begin{array}{l}\text { Khoramirad et al. (2015) } \\
\text { Iran }\end{array}$ & $\begin{array}{l}\text { To determine the relationship between sleep } \\
\text { quality and spiritual wellbeing / religious } \\
\text { activities. }\end{array}$ & Descriptive correlational & $\begin{array}{l}\text { A sample of Muslim women with breast cancer }(\mathrm{n}=80) \text { who } \\
\text { presented at all chemotherapy clinics in Qorn, Iran, was recruited. } \\
\text { The Pittsburgh Sleep Quality Index (Buysse et al. 1989), Spiritual } \\
\text { Wellbeing scale (Idler et al. 1999), and the Religious Activities } \\
\text { questionnaire (Heidari et al. 2013) were used to collect data. }\end{array}$ \\
\hline $\begin{array}{l}\text { Amjad and Bokharey (2015) } \\
\text { Pakistan }\end{array}$ & $\begin{array}{l}\text { To compare the spiritual wellbeing and coping } \\
\text { strategies of patients with generalised anxiety } \\
\text { disorder (GAD) and those with general medical } \\
\text { conditions (GMC). }\end{array}$ & Descriptive correlational & $\begin{array}{l}\text { A sample of } 40 \text { participants with GAD and } 50 \text { participants with } \\
\text { GMC was recruited. }\end{array}$ \\
\hline $\begin{array}{l}\text { Jafari et al. (2014b) } \\
\text { Iran }\end{array}$ & $\begin{array}{l}\text { To investigate the association between spiritual } \\
\text { wellbeing, quality of life, diabetes control } \\
\text { and depression. }\end{array}$ & $\begin{array}{l}\text { Descriptive correlational (multiple regression } \\
\text { analysis was used). }\end{array}$ & $\begin{array}{l}\text { A sample of Iranian Muslim patients with type } 2 \text { diabetes }(\mathrm{n}=203) \\
\text { was recruited from two diabetes care institutes. Controlled diabetes } \\
\text { group }(\mathrm{n}=76) \text { and uncontrolled diabetes group }(\mathrm{n}=127) \text { as } \\
\text { measured by HbA1c. Quality of life and spiritual wellbeing were } \\
\text { measured using the FACIT-Sp (Brady et al. 1999), and depression } \\
\text { was measured using the Patient Health Questionnaire-2 } \\
\text { (Kroenke et al. 2003). }\end{array}$ \\
\hline $\begin{array}{l}\text { Saffari et al. (2013) } \\
\text { Iran }\end{array}$ & $\begin{array}{l}\text { To examine the relationships between } \\
\text { spiritual/religious, demographic and clinical } \\
\text { variables and quality of life. }\end{array}$ & $\begin{array}{l}\text { Descriptive correlational (using hierarchical } \\
\text { regression). }\end{array}$ & $\begin{array}{l}\text { A sample of Iranian Muslims undergoing haemodialysis ( } \mathrm{n}=362) \\
\text { was recruited. } \\
\text { Spiritual coping strategies were measured using the Spiritual Coping } \\
\text { Strategies scale (Baldacchino and Buhagiar 2003), religious beliefs } \\
\text { and practices were measured by the Duke University Religion Index } \\
\text { (Koenig and Büssing 2010), quality of life was measured using the } \\
\text { EQ-5D 3L (The EuroQol Group 1990) and a demographic } \\
\text { questionnaire was used to measure demographics. }\end{array}$ \\
\hline $\begin{array}{l}\text { Jafari et al. (2013) } \\
\text { Iran }\end{array}$ & $\begin{array}{l}\text { To investigate the association between } \mathrm{QOL} \\
\text { and spirituality. }\end{array}$ & $\begin{array}{l}\text { Descriptive correlational (using multiple } \\
\text { stepwise regression analyses). }\end{array}$ & $\begin{array}{l}\text { A sample of breast cancer patients undergoing radiotherapy }(\mathrm{n}=68) \\
\text { was recruited. Spirituality was measured using the FACIT-Sp12 and } \\
\text { quality of life was measured using the European Organisation for } \\
\text { Research and Treatment of Cancer Quality of Life (EORTC QLQ-C30) } \\
\text { scale (Fayers et al. 2001). }\end{array}$ \\
\hline $\begin{array}{l}\text { Jafari et al. (2013) } \\
\text { Iran }\end{array}$ & $\begin{array}{l}\text { To translate and investigate the reliability and } \\
\text { validity of the Persian version of the FACIT-Sp, } \\
\text { including investigating the predictive role of the } \\
\text { instrument in health-related quality of life. }\end{array}$ & $\begin{array}{l}\text { Descriptive correlational (instrument validation). } \\
\text { Confirmatory Factor analysis was conducted. }\end{array}$ & $\begin{array}{l}\text { A sample of cancer patients }(\mathrm{n}=153) \text {. The } 12 \text { item Spiritual } \\
\text { Wellbeing subscale of the FACIT-Sp was used to collect data. }\end{array}$ \\
\hline
\end{tabular}


Table 1. Cont

\begin{tabular}{|c|c|c|c|}
\hline Author (Year), Country & Aim & Design & Sample and Data Collection \\
\hline $\begin{array}{l}\text { Lazenby et al. (2013) } \\
\text { Jordan }\end{array}$ & $\begin{array}{l}\text { To determine the psychometric properties of the } \\
\text { Arabic FACIT-Sp and explore associations } \\
\text { between its three factors (Peace, Meaning and } \\
\text { Faith) and HRQoL. }\end{array}$ & $\begin{array}{l}\text { Descriptive correlational (instrument } \\
\text { validation). }\end{array}$ & $\begin{array}{l}\text { Arabic-speaking cancer patients }(\mathrm{n}=205) \text { who were in treatment at } \\
\text { the King Hussein Cancer Center, Jordan. }\end{array}$ \\
\hline $\begin{array}{l}\text { Musgrave and McFarlane (2004) } \\
\text { Israel }\end{array}$ & $\begin{array}{l}\text { To investigate the relationship among the } \\
\text { antecedent factors of age, ethnicity and education } \\
\text { and the mediating variable of intrinsic religiosity, } \\
\text { extrinsic religiosity, and spiritual wellbeing on } \\
\text { nurses' attitudes towards spiritual care. }\end{array}$ & $\begin{array}{l}\text { Descriptive correlational (path analysis). } \\
\text { Analyses determined the regression of attitudes } \\
\text { towards spiritual care on mediating (spiritual } \\
\text { wellbeing and religiosity) and antecedent } \\
\text { variables (age, ethnicity and education), the } \\
\text { regression of spiritual wellbeing on antecedent } \\
\text { factors, the regression of intrinsic religiosity on } \\
\text { antecedent factors and the regression of extrinsic } \\
\text { religiosity on antecedent factors. }\end{array}$ & $\begin{array}{l}\text { Members of the Israeli Oncology Nursing Society ( } \mathrm{n}=155) \text { were } \\
\text { recruited. The Revised Age Universal Intrinsic/Extrinsic scale } \\
\text { (Gorsuch and McPherson 1989) was used to measure intrinsic and } \\
\text { extrinsic religiosity; the Spiritual Well-Being scale } \\
\text { (Paloutzian and Ellison 1982) was used to measure spiritual } \\
\text { wellbeing; and the Spiritual Care Perspective Survey } \\
\text { (Taylor et al. 1999) was used to measure attitudes towards } \\
\text { spiritual care. }\end{array}$ \\
\hline \multicolumn{4}{|c|}{ Qualitative Studies } \\
\hline $\begin{array}{l}\text { Al-Ghaferi et al. (2017) } \\
\text { Jordan }\end{array}$ & $\begin{array}{l}\text { To explore whether the biopsychosocial spiritual } \\
\text { model of addiction was relevant to an addicted } \\
\text { treatment population in Jordan. }\end{array}$ & $\begin{array}{l}\text { Qualitative } \\
\text { Semi-structured interviews using a topic guide } \\
\text { that covered a participant's experience of } \\
\text { developing addiction and subsequently seeking } \\
\text { treatment. }\end{array}$ & $\begin{array}{l}\text { Men in addiction treatment }(\mathrm{n}=25) \text { in a centre in Amman, Jordan. } \\
\text { Themes were mapped onto the biopsychosocial-spiritual model of } \\
\text { addiction (Engel 1977; Schwartz 1982). }\end{array}$ \\
\hline $\begin{array}{l}\text { Heydari et al. (2016) } \\
\text { Iran }\end{array}$ & $\begin{array}{l}\text { To clarify the meaning and nature of the spiritual } \\
\text { health concept in the context of the practice } \\
\text { of Islam. }\end{array}$ & $\begin{array}{l}\text { Literature review, semi-structured interviews } \\
\text { and observations. Databases searched to } \\
\text { describe the concept of spiritual health from an } \\
\text { Islamic perspective. }\end{array}$ & $\begin{array}{l}\text { A purposive sample of } 5 \text { patients, } 2 \text { nurses, } 1 \text { midwife and } 1 \text { doctor } \\
\text { The modified traditional hybrid model of concept analysis was used } \\
\text { to guide the study consisting of five phases: theoretical phase, initial } \\
\text { fieldwork phase, initial analytical phase, final fieldwork phase and } \\
\text { final analytical phase. }\end{array}$ \\
\hline $\begin{array}{l}\text { Davoodvand et al. (2016) } \\
\text { Iran }\end{array}$ & $\begin{array}{l}\text { To explore the concept of spiritual development in } \\
\text { Iranian Muslim nurses }(\mathrm{n}=17) \text {. }\end{array}$ & Qualitative & $\begin{array}{l}\text { A purposeful sample of Iranian Muslim nurses }(\mathrm{n}=17) \text {. } \\
\text { Semi-structured interviews. }\end{array}$ \\
\hline $\begin{array}{l}\text { Heidari et al. (2015) } \\
\text { Iran }\end{array}$ & $\begin{array}{l}\text { To explore maternal behaviours associated with } \\
\text { the spiritual health of the unborn child. }\end{array}$ & $\begin{array}{l}\text { Qualitative design } \\
\text { Twenty-seven unstructured interviews were } \\
\text { conducted. Interviews lasted between } 30 \text { and } 90 \\
\text { min. }\end{array}$ & $\begin{array}{l}\text { A sample of Iranian mothers }(\mathrm{n}=22) \text { who were pregnant or had } \\
\text { experienced pregnancy. } \\
\text { Content analysis. }\end{array}$ \\
\hline $\begin{array}{l}\text { Hatamipour et al. (2015) } \\
\text { Iran }\end{array}$ & $\begin{array}{l}\text { To explain spiritual needs of cancer patients } \\
\text { in Iran. }\end{array}$ & $\begin{array}{l}\text { Qualitative } \\
\text { Semi-structured interviews using open, } \\
\text { follow-up and in-depth questions. }\end{array}$ & $\begin{array}{l}\text { A sample of cancer patients }(n=18) \text { from referrals to the Cancer } \\
\text { Institute of Imam Khomeini Hospital in Tehran, Iran. } \\
\text { Conventional content analysis }\end{array}$ \\
\hline $\begin{array}{l}\text { Renani et al. (2014) } \\
\text { Iran }\end{array}$ & $\begin{array}{l}\text { To explore the viewpoints of children with asthma } \\
\text { and their families on spiritual and psychological } \\
\text { resources that help adaptation to the disease. }\end{array}$ & $\begin{array}{l}\text { Qualitative } \\
\text { Semi-structured interviews. }\end{array}$ & A purposive sample of nine children and ten parents was recruited. \\
\hline
\end{tabular}


Table 1. Cont.

\begin{tabular}{|c|c|c|c|}
\hline Author (Year), Country & Aim & Design & Sample and Data Collection \\
\hline $\begin{array}{l}\text { Markani et al. (2013) } \\
\text { Iran }\end{array}$ & $\begin{array}{l}\text { To explore how spirituality is experienced by } \\
\text { Muslim oncology nurses. }\end{array}$ & $\begin{array}{l}\text { Qualitative } \\
\text { Semi-structured interviews }\end{array}$ & $\begin{array}{l}\text { Muslim oncology nurses }(\mathrm{n}=24) \text { in Tehran, Iran. } \\
\text { Graneheim and Lundman }(2004) \text { qualitative content } \\
\text { analysis approach. }\end{array}$ \\
\hline $\begin{array}{l}\text { Nir et al. (2013) } \\
\text { Iran }\end{array}$ & $\begin{array}{l}\text { To determine the spiritual experiences of Iranian } \\
\text { Muslim warriors with post-traumatic } \\
\text { stress disorder. }\end{array}$ & $\begin{array}{l}\text { Qualitative } \\
\text { Semi-structured interviews that lasted between } \\
35 \text { and } 75 \mathrm{~min} \text {. }\end{array}$ & $\begin{array}{l}\text { Iranian Muslim warriors who suffer from post-traumatic stress } \\
\text { disorder }(n=22) \text { were recruited from three Medical Center of Tehran. } \\
\text { Conventional content analysis. }\end{array}$ \\
\hline $\begin{array}{l}\text { Nabolsi and Carson (2011) } \\
\text { Jordan }\end{array}$ & $\begin{array}{l}\text { To explore the meaning of spirituality as } \\
\text { experienced by Jordanian Muslim men living with } \\
\text { coronary artery disease (CAD). }\end{array}$ & $\begin{array}{l}\text { Qualitative phenomenological. } \\
\text { Semi-structured interviews using Colaizzi's } \\
\text { phenomenological analysis (Colaizzi 1978). }\end{array}$ & $\begin{array}{l}\text { A purposive sample of } 19 \text { men with CAD was recruited. } \\
\text { Parse's theory of human becoming served to understand the } \\
\text { findings better. }\end{array}$ \\
\hline
\end{tabular}




\subsection{Quantitative Research}

Eighteen quantitative studies met the inclusion criteria. Two of the studies were randomised controlled trials (Moeini et al. 2016; Hosseini et al. 2016) conducted in Iran. One of the trial studies examined the effect of an Islam-based religious program on spiritual wellbeing in elderly patients with hypertension $(n=52)$ in two health centres (Moeini et al. 2016). Spiritual wellbeing was measured using the Spiritual Well-Being scale (Paloutzian and Ellison 1982). No significant differences were noted between the groups before the intervention. However, mean spiritual wellbeing scores were significantly higher in the intervention group post-test and at 1 month follow up than the control group. The second trial study tested the effect of a spiritual intervention on biopsychological health as displayed by gene expression in breast cancer patients $(n=57)$ (Hosseini et al. 2016). The intervention focused on the concepts of prayer, reliance, self-sacrifice, forgiveness, altruism, kindness, remission, repentance, thankfulness, meditation, mantra and death. Findings showed a significant reduction in dopamine gene receptor DRD1-5 expressions in the intervention group in comparison with pre-test scores and the control group. Reduced DRD1-5 gene expression results in reduced cell proliferation, thus better prevention and management of breast cancer patients. Yet, the authors did not specify whether participants were receiving active treatment for their disease, which might have contributed to alternations in gene expression. Furthermore, it was unclear whether other factors, such as demographics, were accounted for in the analysis.

Other quantitative studies investigated the relationship between spirituality (or a related spiritual concept such as spiritual wellbeing or spiritual health) and quality of life (Al-Natour et al. 2017; Cruz et al. 2017; Jafari et al. 2013, 2014b; Lazenby and Khatib 2012; Saffari et al. 2013), caregiver burden (Anum and Dasti 2016), psychological well-being (Anum and Dasti 2016), sleep quality (Khoramirad et al. 2015), and coping strategies (Amjad and Bokharey 2015). Three studies focused on instrument design and validation (Cruz et al. 2016; Jafari et al. 2013; Lazenby et al. 2013).

Three quantitative studies have been conducted with a sample of nurses. The first study investigated the relationship among the antecedent factors of age, ethnicity and education and the mediating variable of intrinsic religiosity, extrinsic religiosity, and spiritual wellbeing on Israeli oncology nurses' $(n=155)$ attitudes towards spiritual care using a descriptive correlational design (Musgrave and McFarlane 2004). Spiritual wellbeing, extrinsic religiosity and education demonstrated direct relationships with attitudes towards spiritual care. Intrinsic and extrinsic religiosity, mediated through spiritual wellbeing, demonstrated indirect relationships with attitudes towards spiritual care. Spiritual wellbeing was reported as a good predictor of nurses' positive attitudes towards spiritual care and it was recommended by Musgrave and McFarlane (2004) that educational initiatives should be developed and implemented to support spiritual wellbeing amongst oncology nurses. Similarly, Musa (2017) used a descriptive correlational design to investigate the frequency of providing aspects of spiritual care intervention and its association with Jordanian Arab Muslim nurses' $(n=355)$ own spiritual wellbeing. Nurses most frequently provided spiritual care that was existential, not overly religious, was commonly used, more traditional and did not require direct nurse involvement. Spiritual wellbeing was important to this sample of nurses. Musa (2017) recommended the need for studies that elicit what kind of spiritual care is being provided by Muslim nurses and the need for further education for nurses on this topic. The third study determined the experiences and perceptions of ICU nurses $(n=145)$ about spirituality and spiritual care using a quantitative descriptive design (Bakir et al. 2017). The Spirituality and Spiritual Care rating scale (McSherry et al. 2002) was used in this study. Almost half of nurses reported that they received spiritual care training and over $60 \%$ provided spiritual care to their patients. Some nurses were found to have insufficient knowledge about spirituality and spiritual care. Only nurses with sufficient knowledge provided spiritual care to patients.

One study recruited a sample of female high school students $(n=340)$ in Iran to investigate determinants of responsibility for health, spiritual health and interpersonal relations and predictive factors based on the theory of planned behaviour (Rezazadeh et al. 2015). Attitude, subjective norms and perceived behavioural control predicted $56 \%$ of behavioural change in spiritual health. The authors' 
recommended that components of the theory of planned behaviour should be considered in developing spiritual health interventions.

\subsection{Qualitative Research}

Ten qualitative studies were sourced. Eight studies were conducted in Iran and two in Jordan. All of the qualitative studies focused on gaining a deeper understanding of the concept of spirituality from a Muslim-Arabic perspective. Three studies included nurses in the sample. The first study used semi structured interviews to explore how spirituality is experienced by Muslim oncology nurses $(n=24)$ in Iran (Markani et al. 2013). Religious and existential themes emerged. The most prominent theme described by the sample was searching for God. The nurses performed practices such as reciting a blessing before starting work, reading the Qur'an, and praying to God. The authors concluded that findings were consistent with the holistic view of Islam that considers all dimensions of personhood simultaneously. The second study, by Davoodvand et al. (2016), also used semi-structured interviews to explore the concept of spiritual development in Iranian Muslim nurses $(n=17)$. Three themes for spiritual development were found: obligation to religion, commitment to ethics, and commitment to law. Factors identified included connection to the limitless divine power, personal and society-orientated ethical codes, and commitment to law. The authors recommended that education for nurses should focus on humanistic principles, ethics and law to improve community and health development. The third study aimed to clarify the meaning and nature of the spiritual health concept in the context of the practice of Islam by conducting a concept analysis using the modified traditional hybrid model of concept analysis (Heydari et al. 2016). This study consisted of a literature review, semi-structured interviews and observations. Data were analysed using content analysis. A purposive sample of 2 nurses, 1 midwife, 5 patients and 1 doctor, was recruited. Attributes of spiritual health included love of the Creator, duty-based life, religious rationality, psychological balance and attention to afterlife. A concept map of spiritual health from an Islamic perspective was developed. Some comparisons were drawn between Western and Islamic culture. For example, the authors stated that in Western culture, spirituality goes beyond religious affiliation and spiritual health embraces a universal concept that is relevant to all. However, by contrast, it is stated that this view of spiritual health is not appropriate within an Islamic perspective where spiritual health is primarily based on a connection with Allah. The authors recommended further studies exploring the difference between Islamic spiritual health and that of other religions and ideologies, to help meet the spiritual needs of patients in the Middle East.

Most studies included patient samples. For example, Harandy et al. (2009) studied the role of spirituality on feelings and attitudes about breast cancer among breast cancer survivors $(n=39)$ using semi-structured interviews. Spirituality was the primary source of psychological support among participants and almost all participants attributed their cancer to the will of God. Yet they actively engaged in medical treatment. This contrasts with Western cultures, in which a belief in an external health locus of control diminishes participation in cancer screening, detection and treatment. The authors stated that findings can help researchers to provide a framework for the development of appropriate and effective culturally sensitive health interventions. Another study by Nabolsi and Carson (2011) used semi-structured interviews and Colaizzi's phenomenological analysis to explore the meaning of spirituality amongst Jordanian Muslim men with CAD ( $n=19)$. Parse's Theory of Human Becoming (Parse 1999) served to understand the findings better. The following themes emerged: developing faith; faith facilitated acceptance of illness and enhanced coping strategies; seeking medical treatment did not conflict with their belief in fate; and spirituality enhanced their inner strength, hope and acceptance of self-responsibility as well as helping them to find meaning and purpose in life. Faith was found to play a major role in the choices made by patients and their acceptance or rejection of personal responsibility in promoting their own future health. It was concluded by the authors that nurses should be present with patients and that true presence is an intentional and reflective approach to care that is grounded in knowledge. Renani et al. (2014) explored 
the viewpoints of children with asthma $(n=9)$ and their parents $(n=10)$ on spiritual and psychological resources that help adaptation to the disease using semi structured interviews. Two main categories emerged: contrive to religious belief consisting of three subcategories-religious beliefs, belief in a divine predestination, and Islamic based patience; and psycho-intellectual management that included five subcategories (psycho-intellectual attention, maintaining family's mental peace, reduction in negative burden of disease, satisfaction from optimal treatment, and matching internal desires with disease conditions). Hatamipour et al. (2015) sought to explain the spiritual needs of cancer patients $(n=18)$ using semi-structured interview and content analysis. Four themes emerged: connection, seeking peace, meaning and purpose, and transcendence. The spiritual needs highlighted in this study are similar to findings from studies conducted in other parts of the world (Murray et al. 2004; Höcker et al. 2014; Stein et al. 2015).

Other samples included in the qualitative studies were Iranian Muslim war veterans who suffered from post-traumatic stress disorder $(n=22)$ (Nir et al. 2013). Semi-structured interview were used to determine the spiritual experience of these warriors. Two main themes emerged: religious attitudes consisting of three subcategories (religious beliefs, religious sentiments, and religious behaviours) and a national sensibility that included two subcategories (patriotism and proud of being injured in my homeland). The specific religious orientation and patriotism of participants was found to aid their improved ability to cope with post-traumatic stress disorder. Meanwhile, Al-Ghaferi et al. (2017) explored whether the biopsychosocial spiritual model of addiction was relevant to men in addiction treatment $(n=25)$ in Jordan using semi-structured interviews. Addiction was associated with spiritual factors such as not praying, not fasting, drinking during Ramadan, and poor relationship with parents. The authors concluded that the biopsychosocial spiritual model of addiction fits well with this cohort, particularly given the relevance of religion in Islamic culture.

Finally, a study by Heidari et al. (2015) explored maternal behaviours associated with the spiritual health of the unborn child using unstructured interviews with Iranian mothers $(n=22)$. The mothers were aged between 24 and 47 years old. Findings revealed one overarching theme of adopting a holistic abstinence pattern in spiritual care of the unborn child. The following seven categories emerged from the data: refusing to eat forbidden food, overcoming mental adversity, regulating one's social interactions, preventing the effects of harmful environments on the senses, avoidance of using insulting and abusive language, keeping one's mind and spirit free from evil traits, and refraining from damaging behaviours. It was concluded by the authors that the findings could inform part of an educational programme for midwives and mothers, as well as informing the provision of prenatal care for expectant mothers.

\section{Discussion}

The aim of this review was to identify and summarise the research conducted to date on the topic of spirituality and health in a Middle East context. A total of 28 articles were sourced and analysed. Eighteen of these were quantitative studies and ten were qualitative studies. Results of this review found that the majority of Middle Eastern research on spirituality and health has been conducted in either Iran or Jordan. Only two studies were found that utilised an experimental/interventional design (Moeini et al. 2016; Hosseini et al. 2016) and both of these were conducted in Iran. This lack of interventional research on spirituality and health is reflected globally (Jim et al. 2015; Moreira-Almeida et al. 2014). In Western societies, the lack of interventional research could most likely be attributed to the ambiguity surrounding defining the concept of spirituality. As discussed earlier in this paper, there has been a struggle to re-conceptualise spirituality in Western societies, due to secularisation, or in other words, the move away from formal institutionalised religion (Puchalski et al. 2014; Weathers et al. 2016; McSherry and Cash 2004; McSherry 2006; Timmins and McSherry 2012). This contrasts significantly with the Middle East context, in which all of the studies analysed in this review illustrated religious Islamic undertones in the findings of the research. For example, the qualitative research included in this review emphasised the importance 
of Islamic beliefs and values on the conceptualisation of spirituality within a Middle Eastern context. The interrelatedness of spirituality and religion in a Middle Eastern context was evident in the findings of the study by Markani et al. (2013). Nurses in this study described searching for God as the most prominent theme in relation to how they experience spirituality. Spirituality was reported as encompassing all dimensions of personhood, including their professional lives as practising nurses. Similar findings were noted in a systematic review by Gielen et al. (2016) of spirituality in Indian palliative care, in which religion featured prominently in all dimensions of spirituality included in prior studies. Gielen et al. (2016) further concluded that contextual adaptations are required if Western models are to be applied to other contexts. However, regardless of the religious roots of understandings of spirituality in the Middle East, many of the attributes and dimensions identified were similar to Western literature e.g., spirituality is concerned with connection, peace, transcendence, and seeking meaning and purpose (Hatamipour et al. 2015; Weathers et al. 2016). Furthermore, in both Western and Middle Eastern contexts, spiritual care is broader than religion and founded on respect for the beliefs and values of each individual (Jafari et al. 2014a). More research exploring the similarities and differences between conceptualizations of spirituality in different religious contexts, and across Western and non-Western settings, would be useful to progress knowledge in this field (Heydari et al. 2016; Zimmer et al. 2016). Furthermore, research investigating the delivery of appropriate models of spiritual care are warranted.

In general, much of the research conducted in the Middle East is similar to research conducted in other parts of the world, including studies with Western populations. Studies in the Middle East have measured spirituality, or spiritual wellbeing, by translating and validating tools that have been developed with Western populations. Similar to research trends globally, studies in the Middle East have looked at the associations between spirituality and many diverse outcomes. For example, this review highlighted the number of studies that have investigated the relationship between spirituality and quality of life (Al-Natour et al. 2017; Cruz et al. 2017; Jafari et al. 2014b), similar to trends in other regions (De Bernardin Gonçalves et al. 2017). Two of the studies included in this review were randomized control trials that tested the effect of Islam-based spiritual interventions and demonstrated positive effects on spiritual wellbeing (Moeini et al. 2016) and on biopsychological health, as measured by gene expressions in blood samples (Hosseini et al. 2016). However, the study by Hosseini et al. (2016) was limited in terms of methodology and analysis. This is in line with the global literature that calls for better designed experimental studies of spirituality and health, to test the impact of spiritual interventions on outcomes such as quality of life, quality of care, patient satisfaction etc. (Moreira-Almeida et al. 2014). In terms of samples recruited for studies in the Middle East, the majority were individuals with cancer similar to the global trend of research on spirituality (Astrow 2017; Oh and Kim 2014).

Several studies explored nurses' spirituality, and findings emphasized the association between nurses' own spiritual wellbeing and their professional practice. This is exemplified in the cultural practices of the nurses studied, for example, many nurses conveyed a blessing on their colleagues every morning before starting work (Markani et al. 2013) and placed huge importance on their obligation to religion and commitment to ethics and law (Davoodvand et al. 2016). Furthermore, it is part of the Middle East culture and beliefs to pray several times a day, including while at work. Thus, many of the nurses included in the studies took time out of work to pray every day. These cultural practices allowed nurses time and space to reflect and pray. From a Western perspective, there has been a huge focus on reflective practice and the need to 'slow down' and be present with patients. There is a wealth of literature published on teaching nurses how to be reflective practitioners (Johns and Freshwater 2009) and how to be fully present with patients (Clarke 2013). Yet, it appears that there is not such a concern or educational need, in relation to reflection on practice, for nurses who follow Muslim or Islamic beliefs and practices. However, the need for further education for nurses and other healthcare professionals in relation to the best methods of delivering spiritual care is evident (Jafari et al. 2014a; Rassool 2000). In both Middle Eastern and Western contexts, factors such as workload, lack of time, lack 
of knowledge, and insufficient resources, most likely contribute to this issue of spiritual care delivery in practice (Balboni et al. 2014; Baldacchino 2008; Cadge et al. 2009; O’Brien 2007; Ronaldson et al. 2012; Wong and Yau 2010).

In terms of limitations of this research, it should be noted that only two databases were searched, thus limiting the findings. Furthermore, the studies sourced were heterogenous in all aspects of the research process (e.g., conceptualisation of spirituality, design, data collection methods, samples etc.). This limited the ability of the researcher to synthesise and analyse the results further. Nonetheless, the author was able to draw some broad comparisons, between Western and Middle Eastern contexts, in relation to research on spirituality and health. Furthermore, the aim of the review was only to identify and summarise the literature conducted on spirituality and health in the Middle East. It was by no means meant to be exhaustive but aimed to provide a 'snapshot' of current trends in research on spirituality across the Middle East.

\section{Conclusions}

Spirituality is a concept that is increasingly securing the interest of researchers and clinicians in nursing and many other disciplines (Cohen et al. 2012). The body of research on spirituality and health in the Middle East has increased. Similar to global research trends, many studies have investigated associations between spirituality and quality of life (Al-Natour et al. 2017; Cruz et al. 2017; Jafari et al. 2014b). The majority of studies in the Middle East were conducted with individuals with cancer, also in line with global research trends (Astrow 2017; Oh and Kim 2014). It is clear that the Middle Eastern perspective is similar to the Western perspective, mostly in terms of design, methods, samples and outcomes of studies. However, the results and findings of previous research highlight the differences between both contexts. In the Middle East, there does not appear to be a major division between religion and spirituality, nor a movement towards using terminology that is non-religious. This can be attributed to the cultural differences between Western and Eastern societies. This review highlights the need to develop models of spiritual care that are appropriate in a Middle Eastern context. There is a need for more research to explore the similarities and differences between conceptualisations of spirituality across different religious and cultural contexts. Further comparative research is also warranted to explore the differences in spirituality and spiritual care amongst populations of patients, as well as nurses, in Western and the Middle Eastern settings.

Conflicts of Interest: The author declares no conflict of interest.

\section{References}

Ahmad, Mahjabeen, and Shamsul Khan. 2016. A model of spirituality for ageing Muslims. Journal of Religion and Health 55: 830-43. [CrossRef] [PubMed]

Al Zaben, Faten, Doaa Ahmed Khalifa, Mohammad Gamal Sehlo, Saad Al Shohaib, Salma Awad Binzaqr, Alae Magdi Badreg, Rawan Ali Alsaadi, and Harold G. Koenig. 2015. Religious involvement and health in dialysis patients in Saudi Arabia. Journal of Religion and Health 54: 713-30. [CrossRef] [PubMed]

Al-Ghaferi, Hamad, Christine Bond, and Catriona Matheson. 2017. Does the biopsychosocial-spiritual model of addiction apply in an Islamic context? A qualitative study of Jordanian addicts in treatment. Drug and Alcohol Dependence 172: 14-20. [CrossRef] [PubMed]

Al-Natour, Ahlam, Sharaf Mohammed Al Momani, and Abeer Ma Qandil. 2017. The relationship between spirituality and quality of life of Jordanian women diagnosed with breast cancer. Journal of Religion and Health 56: 2096-108. [CrossRef] [PubMed]

Amjad, Faiza, and Iram Zehra Bokharey. 2015. Comparison of spiritual well-being and coping strategies of patients with generalized anxiety disorder and with minor general medical conditions. Journal of Religion and Health 54: 524-39. [CrossRef] [PubMed]

Anum, Jawaria, and Rabia Dasti. 2016. Caregiver burden, spirituality, and psychological well-being of parents having children with thalassemia. Journal of Religion and Health 55: 941-55. [CrossRef] [PubMed] 
Astrow, Alan B. 2017. Religion and Spirituality in Oncology. In Spirituality and Religion within the Culture of Medicine: From Evidence to Practice. Oxford: Oxford University Press, p. 129.

Bakir, Ercan, Sevgin Samancioglu, and Serap Parlar Kilic. 2017. Spiritual Experiences of Muslim Critical Care Nurses. Journal of Religion and Health 56: 2118-128. [CrossRef] [PubMed]

Balboni, Michael J., Adam Sullivan, Andrea C. Enzinger, Zachary D. Epstein-Peterson, Yolanda D. Tseng, Christine Mitchell, Joshua Niska, Angelika Zollfrank, Tyler J. VanderWeele, and Tracy A. Balboni. 2014. Nurse and physician barriers to spiritual care provision at the end of life. Journal of Pain and Symptom Management 48: 400-10. [CrossRef] [PubMed]

Baldacchino, Donia R. 2008. Teaching on the spiritual dimension in care to undergraduate nursing students: The content and teaching methods. Nurse Education Today 28: 550-62. [CrossRef] [PubMed]

Baldacchino, Donia R., and Anton Buhagiar. 2003. Psychometric evaluation of the Spiritual Coping Strategies scale in English, Maltese, back-translation and bilingual versions. Journal of Advanced Nursing 42: 558-70. [CrossRef] [PubMed]

Brady, Marianne J., Amy H. Peterman, George Fitchett, May Mo, and David Cella. 1999. A case for including spirituality in quality of life measurement in oncology. Psycho-Oncology 8: 417-28. [CrossRef]

Buysse, Daniel J., Charles F. Reynolds, Timothy H. Monk, Susan R. Berman, and David J. Kupfer. 1989. The Pittsburgh sleep quality index: A new instrument for psychiatric practice and research. Psychiatry Research 28: 193-213. [CrossRef]

Cadge, Wendy, Elaine Howard Ecklund, and Nicholas Short. 2009. Religion and spirituality: A barrier and a bridge in the everyday professional work of pediatric physicians. Social Problems 56: 702-21. [CrossRef]

Clarke, Janice. 2013. Spiritual Care in Everyday Nursing Practice: A New Approach. Hampshire: Palgrave Macmillan.

Cockell, Nell, and Wilfred McSherry. 2012. Spiritual care in nursing: An overview of published international research. Journal of Nursing Management 20: 958-69. [CrossRef] [PubMed]

Cohen, Marlene Z., Lyn M. Holley, Steven P. Wengel, and Rabbi Mendel Katzman. 2012. A platform for nursing research on spirituality and religiosity definitions and measures. Western Journal of Nursing Research 34: 795-817. [CrossRef] [PubMed]

Colaizzi, Paul F. 1978. Psychological research as the phenomenologist views it. In Existential-Phenomenological Alternatives for Psychology. Oxford: Oxford University Press.

Crossman, Joanna. 2010. Conceptualising spiritual leadership in secular organizational contexts and its relation to transformational, servant and environmental leadership. Leadership E Organization Development Journal 31: 596-608.

Crossman, Joanna. 2011. Environmental and spiritual leadership: Tracing the synergies from an organizational perspective. Journal of Business Ethics 103: 553-65. [CrossRef]

Cruz, Jonas Preposi, Donia R. Baldacchino, and Nahed Alquwez. 2016. Validity and reliability of the Spiritual Coping Strategies Scale Arabic version in Saudi patients undergoing haemodialysis. Journal of Renal Care 42: 107-14. [CrossRef] [PubMed]

Cruz, Jonas Preposi, Paolo C. Colet, Nahed Alquwez, Ergie P. Inocian, Raid Salman Al-Otaibi, and Sheikh Mohammed Shariful Islam. 2017. Influence of religiosity and spiritual coping on health-related quality of life in Saudi haemodialysis patients. Hemodialysis International 21: 125-32. [CrossRef] [PubMed]

Dasti, Rabia, and Aisha Sitwat. 2014. Development of a multidimensional measure of Islamic spirituality (MMIS). Journal of Muslim Mental Health 8. [CrossRef]

Davoodvand, Shirmohammad, Abbas Abbaszadeh, and Fazlollah Ahmadi. 2016. Spiritual development in Iranian nurses. Nursing Ethics 24: 936-49. [CrossRef] [PubMed]

De Bernardin Gonçalves, Juliane Piasseschi, Giancarlo Lucchetti, Paulo Rossi Menezes, and Homero Vallada. 2017. Complementary religious and spiritual interventions in physical health and quality of life: A systematic review of randomized controlled clinical trials. PLoS ONE 12: e0186539. [CrossRef] [PubMed]

Engel, George L. 1977. The need for a new medical model: A challenge for biomedicine. Science 196: 129-36. [CrossRef] [PubMed]

Fayers, Peter M., Niel K. Aaronson, Kristin Bjordal, Mogens Grønvold, Desmond Curran, and Andrew Bottomley. 2001. EORTC QLQ-C30 Scoring Manual. Brussels: European Organisation for Research and Treatment of Cancer.

Gielen, Joris, Sushma Bhatnagar, and Santosh K. Chaturvedi. 2016. Spirituality as an ethical challenge in Indian palliative care: A systematic review. Palliative E Supportive Care 14: 561-82. 
Gorsuch, Richard L., and Susan E. McPherson. 1989. Intrinsic/extrinsic measurement: I/E-revised and single-item scales. Journal for the Scientific Study of Religion 28: 348-54. [CrossRef]

Graneheim, Ulla H., and Berit Lundman. 2004. Qualitative content analysis in nursing research: Concepts, procedures and measures to achieve trustworthiness. Nurse Education Today 24: 105-12. [CrossRef] [PubMed]

Halabi, Jehad O. 2006. Psychometric properties of the Arabic version of Quality of Life Index. Journal of Advanced Nursing 55: 604-10. [CrossRef] [PubMed]

Harandy, Tayebeh Fasihi, Fazlollah Ghofranipour, Ali Montazeri, Monireh Anoosheh, Mohsen Bazargan, Eesa Mohammadi, Fazlollah Ahmadi, and Shamsaddin Niknami. 2009. Muslim breast cancer survivor spirituality: Coping strategy or health seeking behavior hindrance? Health Care for Women International 31: 88-98. [CrossRef] [PubMed]

Hatamipour, Khadijeh, Maryam Rassouli, Farideh Yaghmaie, Kazem Zendedel, and Hamid Alavi Majd. 2015. Spiritual needs of cancer patients: A qualitative study. Indian Journal of Palliative Care 21: 61. [PubMed]

Heidari, Saeedeh, Marzieh Raisi, Hoda Ahmari-Tehran, and Ashraf Khorami-Rad. 2013. Relationship between religious activities and spiritual health with glycemic control in patients with diabetes. Iran Journal of Nursing 26: 78-87.

Heidari, Tooba, Saeideh Ziaei, Fazlollah Ahmadi, Eesa Mohammadi, and Jenny Hall. 2015. Maternal experiences of their unborn Child's spiritual care: Patterns of abstinence in Iran. Journal of Holistic Nursing 33: 146-58. [CrossRef] [PubMed]

Heydari, Abbas, Fatemeh Khorashadizadeh, Fatemeh Heshmati Nabavi, Seyed Reza Mazlom, and Mahdi Ebrahimi. 2016. Spiritual health in nursing from the viewpoint of Islam. Iranian Red Crescent Medical Journal 18: e24288. [CrossRef] [PubMed]

Höcker, Anja, Andreas Krüll, Uwe Koch, and A. Mehnert. 2014. Exploring spiritual needs and their associated factors in an urban sample of early and advanced cancer patients. European Journal of Cancer Care 23: 786-94. [CrossRef] [PubMed]

Hosseini, Leili, Farah Lotfi Kashani, Somayeh Akbari, Mohammad Esmaeil Akbari, and Saeedeh Sarafraz Mehr. 2016. The Islamic perspective of spiritual intervention effectiveness on bio-psychological health displayed by gene expression in breast cancer patients. Iranian Journal of Cancer Prevention 9: e6360. [CrossRef] [PubMed]

ICN (International Council of Nurses). 2012. The ICN Code of Ethics for Nurses. Geneva: ICN.

Idler, Ellen L., Shawna V. Hudson, and Howard Leventhal. 1999. The meanings of self-ratings of health: A qualitative and quantitative approach. Research on Aging 21: 458-76. [CrossRef]

Jafari, Najmeh, Ziba Farajzadegan, Ahmadreza Zamani, Fatemeh Bahrami, Hamid Emami, and Amir Loghmani. 2013. Spiritual well-being and quality of life in Iranian women with breast cancer undergoing radiation therapy. Supportive Care in Cancer 21: 1219-25. [CrossRef] [PubMed]

Jafari, Najmeh, Amir Loghmani, and Christina M. Puchalski. 2014. Spirituality and health care in Iran: Time to reconsider. Journal of Religion and Health 53: 1918-22. [CrossRef] [PubMed]

Jafari, Najmeh, Ziba Farajzadegan, Amir Loghmani, Mansoureh Majlesi, and Noushin Jafari. 2014. Spiritual well-being and quality of life of Iranian adults with type 2 diabetes. Evidence-Based Complementary and Alternative Medicine 2014. [CrossRef] [PubMed]

Jim, Heather S. L., James E. Pustejovsky, Crystal L. Park, Suzanne C. Danhauer, Allen C. Sherman, George Fitchett, Thomas V. Merluzzi, Alexis R. Munoz, Mallory A. Snyder, and John M. Salsman. 2015. Religion, spirituality, and physical health in cancer patients: A meta-analysis. Cancer 121: 3760-68. [CrossRef] [PubMed]

Johns, Christopher, and Dawn Freshwater, eds. 2009. Transforming Nursing through Reflective Practice. Oxford: Blackwell Publishing Ltd.

Karakas, Fahri. 2010. Spirituality and performance in organizations: A literature review. Journal of Business Ethics 94: 89-106. [CrossRef]

Khoramirad, Ashraf, Maryam Mousavi, Tahmineh Dadkhahtehrani, and Davoud Pourmarzi. 2015. Relationship between sleep quality and spiritual well-being/religious activities in Muslim women with breast cancer. Journal of Religion and Health 54: 2276-85. [CrossRef] [PubMed]

Koenig, Harold G., and Arndt Büssing. 2010. The Duke University Religion Index (DUREL): A five-item measure for use in epidemological studies. Religions 1: 78-85. [CrossRef]

Koenig, Harold G., Faten Al Zaben, and Doaa Ahmed Khalifa. 2012. Religion, spirituality and mental health in the West and the Middle East. Asian Journal of Psychiatry 5: 180-82. [CrossRef] [PubMed] 
Kroenke, Kurt, Robert L. Spitzer, and Janet B. Williams. 2003. The Patient Health Questionnaire-2: Validity of a two-item depression screener. Medical Care 41: 1284-92. [CrossRef] [PubMed]

Lazenby, Mark, and Jamal Khatib. 2012. Associations among patient characteristics, health-related quality of life, and spiritual well-being among Arab Muslim cancer patients. Journal of Palliative Medicine 15: 1321-24. [CrossRef] [PubMed]

Lazenby, Mark, Jamal Khatib, Feda Al-Khair, and Majdoleen Neamat. 2013. Psychometric properties of the Functional Assessment of Chronic Illness Therapy—Spiritual Well-being (FACIT-Sp) in an Arabic-speaking, predominantly Muslim population. Psycho-Oncology 22: 220-27. [CrossRef]

Lucchetti, Giancarlo, and Alessandra Lamas Granero Lucchetti. 2014. Spirituality, religion, and health: Over the last 15 years of field research (1999-2013). The International Journal of Psychiatry in Medicine 48: 199-215. [CrossRef] [PubMed]

Manitoba's Spiritual Health Care Partners. 2017. Core Competencies for Spiritual Health Care Practitioners. Winnipeg: Manitoba Health, Seniors and Active Living.

Markani, Abdolah Khorami, Farideh Yaghmaei, and Mohammad Khodayari Fard. 2013. Spirituality as experienced by Muslim oncology nurses in Iran. British Journal of Nursing 22: S22-24. [CrossRef]

McSherry, Wilfred. 2006. Making Sense of Spirituality in Nursing and Health Care Practice: An Interactive Approach. London: Jessica Kingsley Publishers.

McSherry, Wilfred, and Keith Cash. 2004. The language of spirituality: An emerging taxonomy. International Journal of Nursing Studies 41: 151-61. [CrossRef]

McSherry, Wilfred, Peter Draper, and Don Kendrick. 2002. The construct validity of a rating scale designed to assess spirituality and spiritual care. International Journal of Nursing Studies 39: 723-34. [CrossRef]

Moberg, David O. 2002. Assessing and measuring spirituality: Confronting dilemmas of universal and particular evaluative criteria. Journal of Adult Development 9: 47-60. [CrossRef]

Moeini, Mahin, Somaye Sharifi, and Mohamed Bagher Kajbaf. 2016. Effect of Islam-based religious program on spiritual wellbeing in elderly with hypertension. Iranian Journal of Nursing and Midwifery Research 21: 566. [PubMed]

Monod, Stéfanie, Mark Brennan, Etienne Rochat, Estelle Martin, Stéphane Rochat, and Christophe J. Büla. 2011. Instruments measuring spirituality in clinical research: A systematic review. Journal of General Internal Medicine 26: 1345. [CrossRef] [PubMed]

Montgomery, Rhonda J. V., Edgar F. Borgatta, and Marie L. Borgatta. 2000. Societal and family change in the burden of care. In Who Should Care for the Elderly. Singapore: World Scientific Publishing, pp. 27-54.

Moreira-Almeida, Alexander, Harold G. Koenig, and Giancarlo Lucchetti. 2014. Clinical implications of spirituality to mental health: Review of evidence and practical guidelines. Revista Brasileira de Psiquiatria 36: 176-82. [CrossRef] [PubMed]

Murray, Scott A., Marilyn Kendall, Kirsty Boyd, Allison Worth, and T. Fred Benton. 2004. Exploring the spiritual needs of people dying of lung cancer or heart failure: A prospective qualitative interview study of patients and their carers. Palliative Medicine 18: 39-45. [CrossRef] [PubMed]

Musa, Ahmad S. 2017. Spiritual care intervention and spiritual well-being: Jordanian Muslim Nurses' Perspectives. Journal of Holistic Nursing 35: 53-61. [CrossRef] [PubMed]

Musgrave, Catherine F., and Elizabeth A. McFarlane. 2004. Israeli oncology nurses' religiosity, spiritual well-being, and attitudes toward spiritual care: A path analysis. Oncology Nursing Forum 31: 321-27. [CrossRef] [PubMed]

Nabolsi, Manar M., and Alexander M. Carson. 2011. Spirituality, illness and personal responsibility: The experience of Jordanian Muslim men with coronary artery disease. Scandinavian Journal of Caring Sciences 25: 716-24. [CrossRef] [PubMed]

NHS (National Health Service). 2009. Spiritual Care Matters: An Introductory Resource for All NHS Scotland Staff. Edinburgh: NHS Education for Scotland.

Nir, Masoud Sirati, Abbas Ebadi, Masoud Fallahi Khoshknab, and Abbas Tavallae. 2013. Spiritual experiences of war veterans who suffer from combat-related post-traumatic stress disorder: A qualitative study. Journal of Religion and Health 52: 719-29.

NMBI (Nursing and Midwifery Board of Ireland). 2005. Requirements and Standards for Nurse Registration Education Programmes. Dublin: NMBI. 
NMBI (Nursing and Midwifery Board of Ireland). 2009. Professional Guidance for Nurses Working with Older People. Dublin: NMBI.

NMBI (Nursing and Midwifery Board of Ireland). 2015. Scope of Nursing and Midwifery Practice Framework. Dublin: NMBI.

Nursing and Midwifery Council. 2010. Standards for Pre-Registration Nursing Education. London: NMC.

Nursing and Midwifery Council. 2014. Standards for Competence for Registered Nurses. London: NMC.

O'Brien, Mary Elizabeth. 2007. Spiritual care: The Nurse's role. In Spirituality in Nursing: Standing on Holy Ground. Burlington: Jones \& Bartlett Learning.

Oh, Pok-Ja, and Soo Hyun Kim. 2014. The effects of spiritual interventions in patients with cancer: A meta-analysis. Oncology Nursing Forum 41: E290-301. [CrossRef] [PubMed]

Paloutzian, Raymond F., and Craig Ellison. 1982. Spiritual well-being scale. In Measures of Religiosity. Edited by Peter C. Hill and Ralph W. Hood. Birmingham: Religious Education Press, pp. 382-85.

Parse, Rosemarie Rizzo. 1999. Illuminations: The Human Becoming Theory in Practice and Research. Burlington: Jones \& Bartlett Learning, vol. 15.

Pawar, Badrinarayan Shankar. 2009. Workplace spirituality facilitation: A comprehensive model. Journal of Business Ethics 90: 375-86. [CrossRef]

Peterman, Amy H., George Fitchett, Marianne J. Brady, Lesbia Hernandez, and David Cella. 2002. Measuring spiritual well-being in people with cancer: The functional assessment of chronic illness therapy-Spiritual Well-being Scale (FACIT-Sp). Annals of Behavioral Medicine 24: 49-58. [CrossRef] [PubMed]

Phipps, Kelly A. 2012. Spirituality and strategic leadership: The influence of spiritual beliefs on strategic decision making. Journal of Business Ethics 106: 177-89. [CrossRef]

Pike, Joanne. 2011. Spirituality in nursing: A systematic review of the literature from 2006-10. British Journal of Nursing 20: 743-49. [CrossRef] [PubMed]

Puchalski, Christina M., Benjamin Blatt, Mikhail Kogan, and Amy Butler. 2014. Spirituality and health: The development of a field. Academic Medicine 89: 10-16. [CrossRef] [PubMed]

Rassool, G. Hussein. 2000. The crescent and Islam: Healing, nursing and the spiritual dimension. Some considerations towards an understanding of the Islamic perspectives on caring. Journal of Advanced Nursing 32: 1476-84. [CrossRef] [PubMed]

Renani, Houshang Alijani, Fatemeh Hajinejad, Esmaeil Idani, and Maryam Ravanipour. 2014. Children with asthma and their families' viewpoints on spiritual and psychological resources in adaptation with the disease. Journal of Religion and Health 53: 1176-89. [CrossRef] [PubMed]

Rezazadeh, Afsaneh, Mahnaz Solhi, and Kamal Azam. 2015. Determinants of responsibility for health, spiritual health and interpersonal relationship based on theory of planned behavior in high school girl students. Medical Journal of the Islamic Republic of Iran 29: 204. [PubMed]

Ronaldson, Susan, Lillian Hayes, Christina Aggar, Jennifer Green, and Michele Carey. 2012. Spirituality and spiritual caring: Nurses' perspectives and practice in palliative and acute care environments. Journal of Clinical Nursing 21: 2126-35. [CrossRef] [PubMed]

Ryff, Carol D. 1989. Happiness is everything, or is it? Explorations on the meaning of psychological well-being. Journal of Personality and Social Psychology 57: 1069. [CrossRef]

Saffari, Mohsen, Amir H. Pakpour, Maryam K. Naderi, Harold G. Koenig, Donia R. Baldacchino, and Crystal N. Piper. 2013. Spiritual coping, religiosity and quality of life: A study on Muslim patients undergoing haemodialysis. Nephrology 18: 269-75. [CrossRef] [PubMed]

Schwartz, Gary E. 1982. Testing the biopsychosocial model: The ultimate challenge facing behavioral medicine? Journal of Consulting and Clinical Psychology 50: 1040. [CrossRef] [PubMed]

Stein, Emma M., Evelyn Kolidas, and Alyson Moadel. 2015. Do spiritual patients want spiritual interventions? A qualitative exploration of underserved cancer patients' perspectives on religion and spirituality. Palliative $\mathcal{E}$ Supportive Care 13: 19-25.

Taylor, Elizabeth Johnston, Martha F. Highfield, and Madalon Amenta. 1999. Predictors of oncology and hospice nurses' spiritual care perspectives and practices. Applied Nursing Research 12: 30-37. [CrossRef]

The EuroQol Group. 1990. EuroQol-A new facility for the measurement of health-related quality of life. Health Policy 16: 199-208.

Timmins, Fiona, and Wilf McSherry. 2012. Spirituality: The Holy Grail of contemporary nursing practice. Journal of Nursing Management 20: 951-57. [CrossRef] [PubMed] 
Weathers, Elizabeth, Geraldine McCarthy, and Alice Coffey. 2016. Concept analysis of spirituality: An evolutionary approach. Nursing Forum 51: 79-96. [CrossRef] [PubMed]

Williams, David R., and Michelle J. Sternthal. 2007. Spirituality, religion and health: Evidence and research directions. Medical Journal of Australia 186: S47. [PubMed]

Wong, Ka Fai, and Sui Yu Yau. 2010. Nurses' experiences in spirituality and spiritual care in Hong Kong. Applied Nursing Research 23: 242-44. [CrossRef] [PubMed]

Zimmer, Zachary, Carol Jagger, Chi-Tsun Chiu, Mary Beth Ofstedal, Florencia Rojo, and Yasuhiko Saito. 2016. Spirituality, religiosity, aging and health in global perspective: A review. SSM-Population Health 2: $373-81$. [CrossRef] [PubMed]

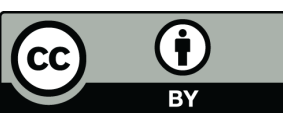

(C) 2018 by the author. Licensee MDPI, Basel, Switzerland. This article is an open access article distributed under the terms and conditions of the Creative Commons Attribution (CC BY) license (http:/ / creativecommons.org/licenses/by/4.0/). 